\section{Height Control of Poinsettia Using Photoselective Filters}

Sean C. Clifford

Horticulture Research International, Wellesbourne, Warwick, CV35 9EF, United Kingdom

Erik S. Runkle ${ }^{1}$

Department of Horticulture, Michigan State University, East Lansing, MI 48824-1325

\section{F. Allen Langton and Andrew Mead}

Horticulture Research International, Wellesbourne, Warwick, CV35 9EF, United Kingdom

\author{
Shirley A. Foster \\ Horticulture Research International, Efford, Lymington, Hampshire SO41 \\ OLZ, United Kingdom
}

\section{Simon Pearson \\ Department of Horticulture, University of Reading, Reading, Berkshire, RG6 6AS, United Kingdom}

Royal D. Heins

Department of Horticulture, Michigan State University, East Lansing, MI 48824-1325

Additional index words. Euphorbia pulcherrima, far-red light, phytochrome, spectral filters, stem extension

Abstract. Most commercial markets require growers of poinsettia (Euphorbia pulcherrima Willd. ex Klotzsch.) to produce plants within strict height specifications. Plant growthretarding chemicals (PGRs) are commonly used to limit internode extension, but in some countries, growers are being pressured to reduce chemical use. Recently, a photoselective film was developed that specifically reduces the transmission of far-red light [(FR), 700 to $800 \mathrm{~nm}$ ], offering an alternative strategy for height control. Two complementary trials, one in the United Kingdom and one in the United States, showed that plants grown under the FR film for 10 to 12 weeks were $\approx 20 \%$ shorter than control plants growing under neutral density (ND) films transmitting a similar photosynthetic photon flux as the FR film. In the United Kingdom trial, the FR filter delayed time to $50 \%$ bract color and first visible cyathia by 6.0 and 3.5 days, respectively, but did not influence time to final harvest. In the United States trial, plants under the FR film had an average of $25 \%$ more axillary branches than those under the ND film. In addition, the effects of reduced red $[(R), 600$ to $700 \mathrm{~nm}]$ and blue $[(B), 400$ to $500 \mathrm{~nm}]$ light on internode length, plant biomass, and axillary branching were determined using other photoselective plastics. Compared with plants under the ND film, internode length was $9 \%$ or $71 \%$ greater in plants grown under environments deficient in $B$ or $R$, respectively. Our results indicate that poinsettia is highly sensitive to the $R:$ FR ratio, and that spectral manipulation has potential for height control of commercial poinsettia crops.

Poinsettias are one of the most economically valuable floriculture plants in the world. In 2001, the wholesale value of poinsettias was $>\$ 256$ million in the United States alone [U.S. Dept. of Agriculture (USDA), 2002]. Successful poinsettia production requires that plants meet preset height specifications. Plants that are too tall or too short can cause

shipping challenges and may have reduced value. Poinsettias are commercially produced at high densities (up to 12 plants $/ \mathrm{m}^{2}$ in the United Kingdom, depending on cultivar) and thus compete for available light during production. If growth is left uncontrolled, particularly early in the season when ambient temperatures are highest, plants develop

Received for publication 13 June 2003. Accepted for publication 30 Sept. 2003. S.C. Clifford, F.A. Langton, and S. Pearson gratefully acknowledge the Horticultural Development Council for funding assistance in the U.K (project code PC 155), British Polythene Ltd. and Reading Univ. for providing FR filter materials, Sarah Smith for spectral analysis, and Ann Peek for technical assistance. E.S. Runkle and R.D. Heins gratefully acknowledge the Michigan Agricultural Experiment Station, funding by greenhouse growers supportive of Michigan State Univ. floricultural research, and British Polythene, Ltd. for providing the FR filter materials.

${ }^{1}$ To whom reprint requests should be addressed. E-mail address: runkleer@msu.edu extended internodes and weak branches, which contribute to loss of lower leaves and reduced marketability and postharvest life. To avoid these problems, greenhouse growers commonly rely on repeated applications of plant growth regulating chemicals (PGRs) such as chlormequat, paclobutrazol, or daminozide, which add costs for chemical purchase and labor to apply the PGRs.

Although PGRs can effectively reduce internode extension, alternative nonchemical techniques to control plant height are needed to meet environmental pressures for reduced chemical use in horticulture, and to anticipate the potential restrictions of some PGR chemicals in some countries. A variety of cultural and environmental techniques have been suggested including mechanical conditioning (Garner et al., 1997; Johjima et al., 1992), genetic manipulation (Jordan et al., 1995), water and nutrient management (Liptay et al., 1997; Melton and Dufault, 1991), and temperature manipulation (Erwin and Heins, 1995; Heins and Erwin, 1990; Langton and Cockshull, 1997). Of these, temperature manipulation is the only strategy that has been widely implemented in commercial production. Ideally, a low temperature will be maintained throughout the day to limit stem elongation, but this is difficult to achieve when the ambient temperature, solar radiation, or both, are high during the forcing period for poinsettias. An alternative temperature strategy is to markedly reduce the temperature at or just before the onset of the photoperiod when ambient temperature would be expected to be lowest and maintain this lower temperature for 2 to $4 \mathrm{~h}$ after sunrise, a strategy known as DROP. DROP can be effective in reducing poinsettia height (Cockshull et al., 1994; Ueber and Hendriks, 1992) and is widely used commercially for height control (Langton, 1998; Myster and Moe, 1995). However, the implementation of DROP can also be difficult early in the poinsettia production season, when thermal and solar loads are often high.

An alternative approach to limit extension growth is to manipulate light quality using spectral filters to reduce the transmission of far-red radiation [(FR), 700 to $800 \mathrm{~nm}$ ]. Leaves absorb most red light [(R), 600 to $700 \mathrm{~nm}]$, but transmit and reflect most FR radiation. Thus, when plants are closely spaced, $\mathrm{R}$ within the canopy declines to a greater extent than FR, and the $\mathrm{R}$ : FR is reduced. This causes many plants to respond by increasing extension growth, a phenomenon known as the shade avoidance syndrome (Aphalo et al., 1999; Holmes and Smith, 1977a, b). Similarly, increasing the $\mathrm{R}$ :FR experimentally has been shown to reduce extension growth (Smith, 1982). This response to the $\mathrm{R}: \mathrm{FR}$ offers an alternative means of controlling poinsettia extension growth through modification of the greenhouse environment instead of chemical PGR applications.

Research groups have been manipulating ambient light using photoselective filters to modify plant growth characteristics of various herbaceous crops (McMahon et al., 1990; Oyaert et al., 1999; Rajapakse et al., 1999; 
Runkle and Heins, 2001; van Haeringen et al., 1998). Poinsettia is sensitive to the $R$ : FR and extension growth has been controlled using copper sulphate liquid filters that selectively exclude FR (McMahon and Kelly, 1990). However, liquid filters can only be used in double layered greenhouses that have been specifically designed for the purpose, and the high capital costs of these and health and safety issues associated with handling fluid filters make them impractical for commercial operations (Rajapakse et al., 1999).

In the past decade, lightweight flexible plastics have been engineered to selectively reflect a significant portion of FR. Here, we report research conducted in the United Kingdom and United States to determine the effects of an FR plastic filter on growth and development of two cultivars of the short-day plant poinsettia. Trials in the United States tested the FR filter's effects on extension growth during the vegetative growth phase, as well as films that selectively reduced the transmission of $\mathrm{R}$ and blue [(B), 400 to $500 \mathrm{~nm}$ ] light. Trials in the United Kingdom evaluated plant responses to the FR filter throughout vegetative and reproductive phases, to the marketing stage. Plants grown under the FR filter were compared to those grown under neutral filters with or without other height-control strategies.

\section{Materials and Methods}

\section{United Kingdom FR filter and temperature DROP treatments (Expt. 1)}

Plant culture. Uniform rooted vegetative cuttings of poinsettia 'Spotlight' (Dummen ex. Hollyacre Plants, U.K.) were transplanted on 27 July 1998 into 13-cm (1-L) pots containing Sinclair speciality poinsettia compost(William Sinclair Holdings plc, Lincoln, U.K). To reduce moisture loss and protect from high irradiance, plants were established under a single layer of woven polypropylene horticultural shade cloth $\left(17 \mathrm{~g} \cdot \mathrm{m}^{-2}\right.$, Tildenet, Bristol, U.K.). Plants were pinched to six nodes 2 weeks after receipt, and grown under ambient daylight and photoperiod conditions in Efford, United Kingdom (lat. $51^{\circ} \mathrm{N}$ ) in two glasshouse compartments. Plants were spaced from an initial density of 59 plants $/ \mathrm{m}^{2}$ to a final density of 9 plants $/ \mathrm{m}^{2}$ by 23 Sept. 1998. $\mathrm{CO}_{2}$ was enriched during the day to $500 \mu \mathrm{L} \cdot \mathrm{L}^{-1}$ when vents were $<3 \%$ open. For the first 4 weeks, plants were fertilized with $\mathrm{CaNO}_{3}\left(125 \mathrm{mg} \cdot \mathrm{L}^{-1} \mathrm{~N}\right)$. For the balance of the experiment, plants received $\mathrm{N}$ at 125 to $225 \mathrm{mg} \cdot \mathrm{L}^{-1}, \mathrm{P}$ at 40 to $50 \mathrm{mg} \cdot \mathrm{L}^{-1}$ and $\mathrm{K}$ at $175-180 \mathrm{mg} \cdot \mathrm{L}^{-1}$. Micronutrients $[3.3 \mathrm{Fe}-1.7$ $\mathrm{Cu}-1.7 \mathrm{Mn}-0.6 \mathrm{Zn}-0.8 \mathrm{~B}-0.02 \mathrm{Mo} \mathrm{mg} \cdot \mathrm{L}^{-1}$ (Librel BMX, Interlates, Bradford, U.K.)] and chelated calcium (CaEDTA) were included, each at $0.10 \mathrm{~g} \cdot \mathrm{L}^{-1}$.

Experimental treatments. Plants were grown in a glasshouse compartment with day/night temperature setpoints of $19 / 20^{\circ} \mathrm{C}$ from 2 Aug. to $27 \mathrm{Sept}$., $16 / 18^{\circ} \mathrm{C}$ from $27 \mathrm{Sept}$. to 25 Oct., and $16 / 16^{\circ} \mathrm{C}$ from 25 Oct. to final harvest. In one compartment, a FR filter (described by van Haeringen et al., 1998) was used as permanent screening beginning $26 \mathrm{Aug}$. over and around the two replicate plots (n $=40$ plants per plot). In a separate compartment, neutral shading material was provided to deliver a similar photosynthetic photon flux $(P P F)$. Spectral transmission under the FR filter was measured using a spectroradiometer with an M300EA monochromator (Bentham Instruments; Reading, United Kingdom) and is shown in Fig. 1. Incident solar radiation decreased during the experiment, from per day in November (Fig. 2). A system of vents was used to minimize increases in air temperature around the screened plants. Air temperatures under the filters were measured using shielded thermistors and logged using a datalogger (Grant Instruments, Cambridge, U.K.). Air temperature under the filters was $\leq 2{ }^{\circ} \mathrm{C}$ higher than the compartment air temperature.

One group of plants was grown in the neutral-density compartment with PGR applications. Plants were treated with chlormequat chloride (Cycocel) at $1.5 \mathrm{~mL} \cdot \mathrm{L}^{-1}, 46 \%$ a.i. (Fargro, Littlehampton, U.K), applied as a light drift $\left(90 \mathrm{~mL} \cdot \mathrm{m}^{-2}\right.$ at final spacing) to the crop canopy. PGR treatments were replicated twice. Six plants per replicate plot were measured weekly beginning 12 Aug., which was used to determine when to apply chlormequat chloride. Timing and frequency of PGR applications were determined by reference to a target growth curve (Fisher and Mackensen, 1997). Nineteen applications were made to meet desired height specifications.

In a separate compartment, plants were grown without an FR filter, under a DROP temperature regimen. The temperature set point was reduced by $8^{\circ} \mathrm{C}$ for $3 \mathrm{~h}$ beginning at dawn from 27 Aug. to 21 Oct. Temperature set points during the remainder of the day were adjusted so that 24-h average temperatures were similar to that in the control temperature $\approx 12 \mathrm{~mol} \cdot \mathrm{m}^{-2}$ per day in August to $\approx 2.7 \mathrm{~mol} \cdot \mathrm{m}^{-2}$

regimen. The DROP treatment was terminated on 21 Oct. so bract expansion would not be compromised.

Actual mean daily temperature in the two temperature compartments were maintained to within $\pm 1{ }^{\circ} \mathrm{C}$ of each other, except for the week of 12 Oct., when temperatures in the DROP treatment averaged $2.0^{\circ} \mathrm{C}$ below those of the standard temperature treatment (Fig. 2). Temperature set points of $19{ }^{\circ} \mathrm{C}$ day $/ 20{ }^{\circ} \mathrm{C}$ night were frequently exceeded early in the season due to high irradiance. Because of this, the average magnitude of DROP provided was generally small $\left(<2.5^{\circ} \mathrm{C}\right)$ through the week of 21 Sept., only increasing to $>4^{\circ} \mathrm{C}$ after 28 Sept. (Fig. 2). The maximum mean DROP (weekly average during $3 \mathrm{~h}$ post-dawn) was $7.9^{\circ} \mathrm{C}$ in the final week the treatment was applied.

Measurements and analysis. Dates when $50 \%$ of plants were showing bract color and visible cyathia were recorded, and time to bract color, visible cyathia, and final harvest were determined for 15 plants per plot. The final harvest stage was judged using commercial criteria: bracts were fully colored, with the exception of one bract subtending the inflorescence which was partially green. Plant height was measured upon termination of the DROP treatment (21 Oct.) and when plants reached the harvest stage (18 Nov.). Data were analyzed by analysis of variance (ANOVA) using Genstat version 5 (Payne, 2000).

\section{United States experiment: FR, R, and B spectral filters (Expt. 2)}

Plant material and culture. Nonpinched rooted 'Freedom Red' poinsettia cuttings were obtained from a commercial greenhouse grower on 23 July 1998 (Rep 1) and 15 Sept. 1998 (Rep 2). On each occasion, plants were held for $2 \mathrm{~d}$ before transplanting into $13-\mathrm{cm}(1.1-\mathrm{L})$ plastic containers. Plants

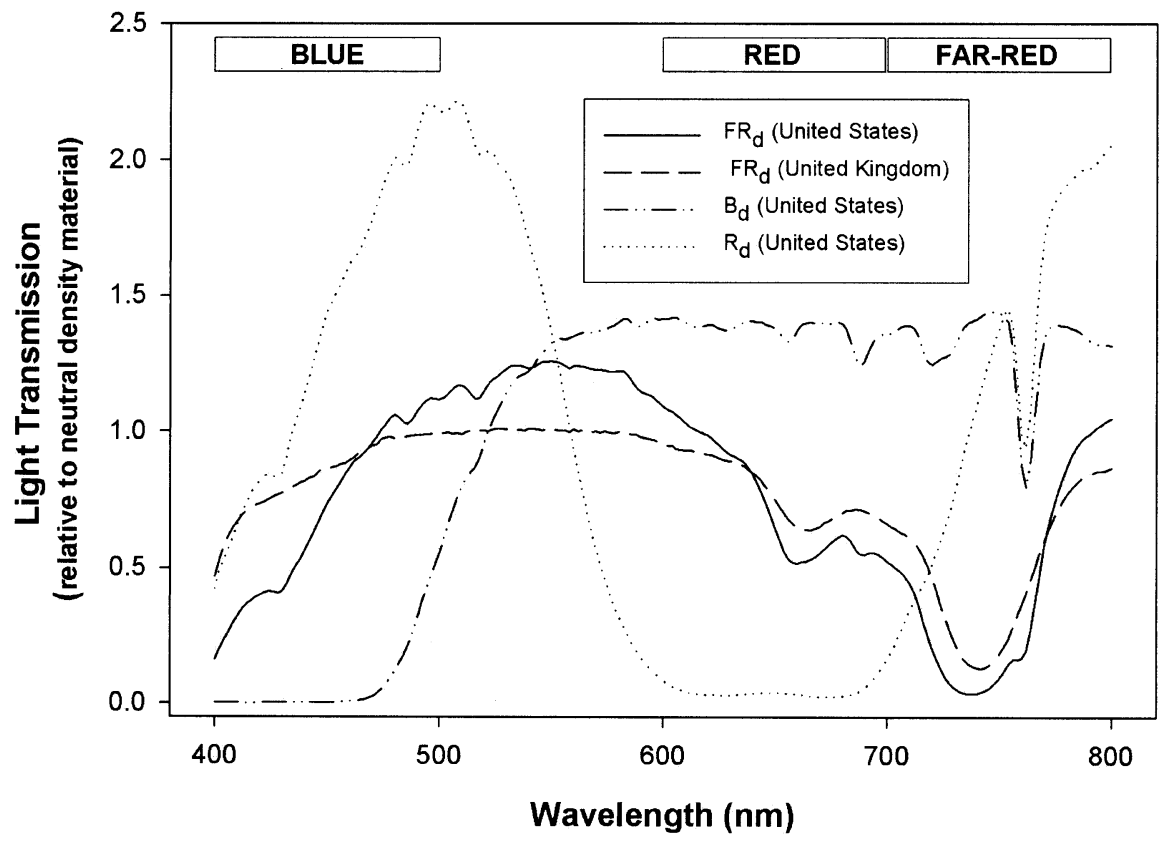

Fig. 1. Normalized transmission spectra under filter treatments that selectively reduced the transmission of far-red (FR) light, blue (B) light, or red (R) light creating far-red deficient $\left(\mathrm{FR}_{\mathrm{d}}\right)$, blue deficient $\left(\mathrm{B}_{\mathrm{d}}\right)$, or red deficient $\left(\mathrm{R}_{\mathrm{d}}\right)$ environments. 


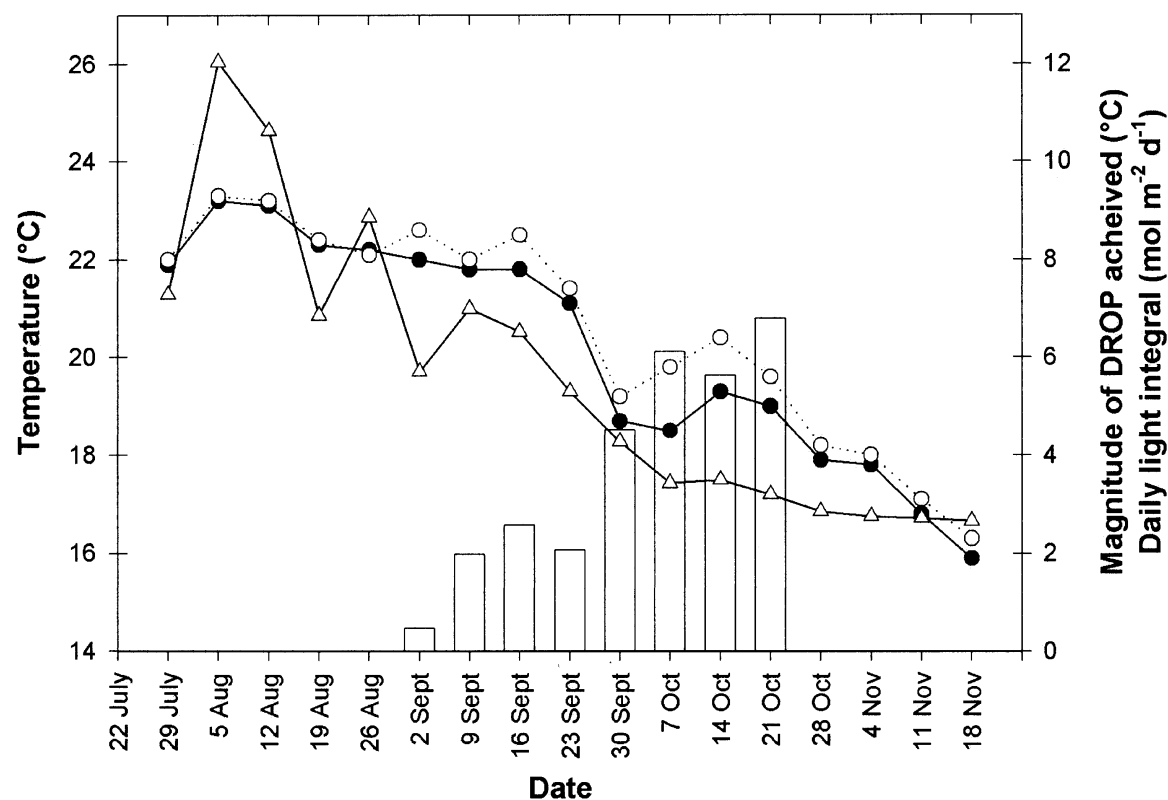

Fig. 2. Actual weekly mean temperatures in the standard ( ) and DROP $(\mathbf{O})$ temperature regimens, ambient solar daily light integral $(\triangle)$, and mean DROP delivered (bars) in each week during the three hour post-dawn period (United Kingdom data).

Table 1. Average daily temperature and light integral, quantum ratios of red (R, 600 to $700 \mathrm{~nm}$ ) to far red (FR, 700 to $800 \mathrm{~nm}$ ) light, and calculated phytochrome photoequilibria $\left(\mathrm{P}_{\mathrm{f}} / \mathrm{P}_{\mathrm{tal}}\right)$ under filters in the United States trial with solar radiation or high pressure sodium (HPS) lamps as the sole light source (Sager et al., 1988). ND = neutral density; B = blue (400 to $500 \mathrm{~nm})$ light.

\begin{tabular}{|c|c|c|c|c|c|c|c|c|}
\hline \multirow[b]{3}{*}{ Filter } & \multirow{2}{*}{\multicolumn{2}{|c|}{$\begin{array}{c}\text { Average } \\
\text { temperature }\left({ }^{\circ} \mathrm{C}\right)\end{array}$}} & \multirow{2}{*}{\multicolumn{2}{|c|}{$\begin{array}{l}\text { Average daily light } \\
\text { integral }\left(\mathrm{mol} \cdot \mathrm{m}^{-2} \text { per day) }\right.\end{array}$}} & \multicolumn{4}{|c|}{ Light source } \\
\hline & & & & & \multicolumn{2}{|c|}{ Solar radiation } & \multicolumn{2}{|c|}{ HPS lamps } \\
\hline & $\overline{\operatorname{Rep} 1}$ & $\operatorname{Rep} 2$ & Rep 1 & Rep 2 & $\overline{\mathrm{R}: \mathrm{FR}}$ & $\mathrm{P}_{\mathrm{fr}} / \mathrm{P}_{\text {total }}$ & $\mathrm{R}: \mathrm{FR}$ & $\mathrm{P}_{\text {fr }} / \mathrm{P}_{\text {total }}$ \\
\hline FR & 22.2 & 20.8 & 5.9 & 5.5 & $1.74^{z}$ & $0.798^{y}$ & 5.73 & 0.873 \\
\hline ND & 22.1 & 20.6 & 5.6 & 5.7 & 1.07 & 0.715 & 3.98 & 0.850 \\
\hline $\mathrm{R}$ & 22.2 & 20.9 & 5.9 & 4.9 & 0.04 & 0.399 & 0.15 & 0.624 \\
\hline B & 22.0 & 20.4 & 5.8 & 5.3 & 1.05 & 0.723 & 3.82 & 0.851 \\
\hline
\end{tabular}

${ }^{\mathrm{z}} \mathrm{R}$ : FR for the FR filter used in the United Kingdom (U.K.) experiment was 2.04 .

${ }^{\mathrm{y}} \mathrm{P}_{\mathrm{fr}} / \mathrm{P}_{\text {total }}$ for the FR filter used in the U.K. experiment was 0.783 .

averaged 6.5 and 8.7 nodes for Reps 1 and 2 , respectively. Plants were grown in a soilless medium composed of composted pine bark, vermiculite, Canadian sphagnum peat, coarse perlite with a wetting agent, and lime (High Porosity Mix, Strong-Lite Products, Pine Bluff, Ark.). Plants were fertilized at every irrigation with a nutrient solution of well water acidified with $\mathrm{H}_{2} \mathrm{SO}_{4}$ to a titratable alkalinity of $130 \mathrm{mg} \cdot \mathrm{L}^{-1}$ of $\mathrm{CaCO}_{3}$ and water soluble fertilizer $\left[125 \mathrm{~N}-12 \mathrm{P}-125 \mathrm{~K} \mathrm{mg} \cdot \mathrm{L}^{-1}\right.$ plus $1.0 \mathrm{Fe}-0.5 \mathrm{Mn}-0.5 \mathrm{Zn}-0.5 \mathrm{Cu}-0.1 \mathrm{~B}-0.1 \mathrm{Mo}$ $\mathrm{mg} \cdot \mathrm{L}^{-1}$ (MSU Special, Greencare Fertilizers, Chicago)].

Experimental treatments. Experiments were conducted in a glasshouse in East Lansing, Mich. (lat. $43^{\circ} \mathrm{N}$ ). Four different light quality environments were created using cladding materials of neutral density (ND) or plastics that selectively reduced the transmission of FR, R, and B light creating far-red deficient $\left(\mathrm{FR}_{\mathrm{d}}\right)$, red deficient $\left(\mathrm{R}_{\mathrm{d}}\right)$ and blue deficient $\left(\mathrm{B}_{\mathrm{d}}\right)$, environments respectively, as described by Runkle and Heins (2001). The FR filter was similar to that used in the United Kingdom trial, but was from a different production batch. Spectral transmissions were measured under each of the filters using a portable spectroradiometer (LI-1800, LICOR, Lincoln, Nebr.) and are shown in Fig. 1. The quantum $\mathrm{R}: \mathrm{FR}$ for each light environment are given in Table 1 .

A 16-h photoperiod was delivered to promote vegetative growth using a combination of solar radiation and supplementary lighting from high-pressure sodium (HPS) lamps positioned above the filters. From $0600 \mathrm{HR}$ to $2200 \mathrm{HR}$, HPS lamps provided a supplemental $P P F$ of $\approx 35 \mu \mathrm{mol} \cdot \mathrm{m}^{-2} \cdot \mathrm{s}^{-1}$ at canopy level when the ambient glasshouse $P P F$ was $<200 \mu \mathrm{mol} \cdot \mathrm{m}^{-2} \cdot \mathrm{s}^{-1}$, and were terminated when the ambient $P P F$ was $>400 \mu \mathrm{mol} \cdot \mathrm{m}^{-2} \cdot \mathrm{s}^{-1}$. The quantum ratios under the filters were calculated with solar radiation or the lamps as the only light source (Table 1). The average daily light integral was measured at canopy level under each filter treatment with line quantum sensors connected to a CR10 datalogger (Campbell Scientific, Logan, Utah). Each of the sensors was independently calibrated under the filters using a LI-COR spectroradiometer. All plants were grown at a set point temperature of $20^{\circ} \mathrm{C}$ with control and monitoring as reported by Runkle and Heins (2001). Actual average daily air temperature and $P P F$ light integral were calculated under each filter (Table 1).
Data collection and analysis. Twenty plants per replication were placed under each of the filter materials and were harvested after 10 weeks of growth. At harvest, final node number (including only those in which leaves were at least half expanded) on the main stem, plant height (not including the container), number of axillary breaks on the main stem, and shoot (stems and leaves) fresh weight were measured. Internode length was calculated by subtracting initial plant height from final plant height and dividing the difference by the node count increase from the start of forcing. Shoots were dried at $55^{\circ} \mathrm{C}$ for $2 \mathrm{~d}$, and dry weight was recorded. Data were analyzed using SAS's (SAS Institute, Cary, N.C.) ANOVA and general linear model (GLM) procedures, and mean separation procedure (pdiff) with $P<0.05$.

\section{Results}

FR filter and temperature DROP treatments (Expt. 1). When the DROP treatment was terminated (21 Oct.), height of plants grown in the DROPregimen was similar to that of plants grown in the standard temperature regimen (Table 2). In contrast, plants grown under the FR filter were $6.8 \mathrm{~cm}$ (24\%) shorter than untreated plants, a degree of height control similar to that from PGR treatments. At marketing (18 Nov.), plants treated with PGRs were $12 \mathrm{~cm}$ $(28 \%)$ shorter than control plants (Table 2). Within 1 week, plants under the FR filter were shorter than plants grown with DROP or under the ND filter (data not shown).

Temperature regimen had no effect on time to $50 \%$ of plants showing bract color or time to $50 \%$ of plants with visible cyathia, but DROP did reduce total time to marketing (Table 2). Production under the FR filter delayed color development by $6 \mathrm{~d}$ compared to nonfiltered plants in the same temperature regime $(P<0.05)$, and delayed flowering (first visible cyathia) by $3.5 \mathrm{~d}(P<0.05)$.

$F R, R$, and $B$ spectral filters (Expt. 2). After 10 weeks, internode extension differed significantly in each of the four spectral environments. Compared to the ND treatment, internode lengths were $71 \%$ and $9 \%$ greater under the $\mathrm{R}$ and $\mathrm{B}$ filters, respectively $(P$ $<0.05)$, and $20 \%$ shorter under the FR filter $(P$ $<0.05$; Fig 3A). Under the ND screen, plants developed an average of 5.8 axillary branches. Branching was markedly depressed under the $\mathrm{R}$ filter (1.6 branches), but significantly enhanced under the FR filter (7.3 branches; Fig. 3B). Relative to the ND screen, fresh weight was not affected by the $R$ and FR filters, but was significantly increased under the B filter (Fig. 3C). Plant dry weight under the photoselective filters was similar to that under the ND screen (Fig. 3D)

\section{Discussion}

These studies demonstrate that significant height reductions ( $20 \%$ to $25 \%$ ) were achieved when poinsettias were grown under fixed FR plastic filters under either United Kingdom or United States conditions. The reductions 

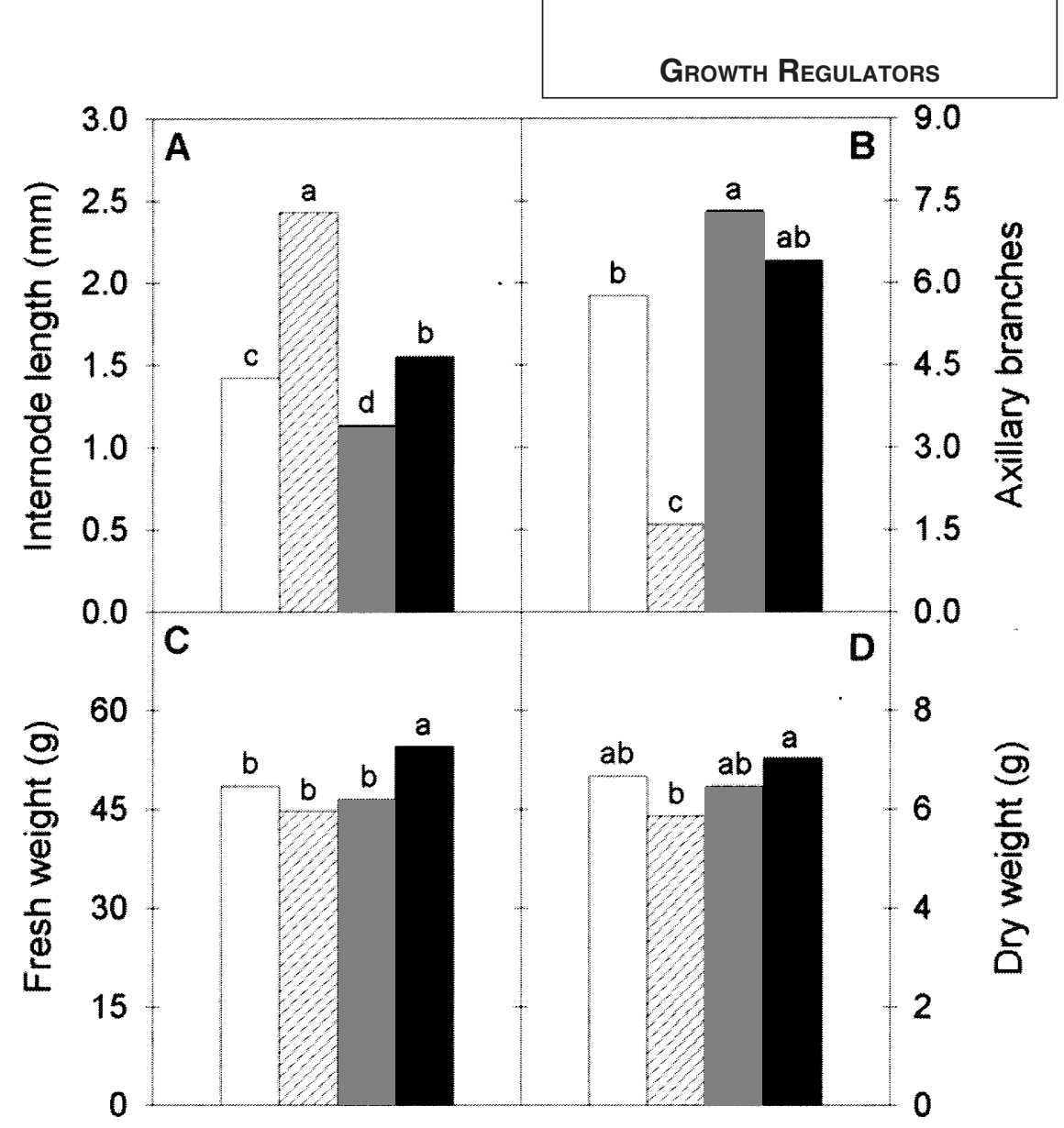

Fig. 3. Effects of a neutral density screen (open bar) or red (R; open bar, diagonal hatch), far red (FR; solid gray bar) or blue (B; solid black bar) spectral filters on internode length (A), number of axillary branches (B), fresh weight (C) and dry weight (D) of poinsettia plants after 10 weeks of vegetative growth. Each bar represents the mean of 40 plants. Values with the same letter are not statistically different at $P=0.05$.

in plant height are similar to those observed in other shade-avoiding plants under the same filter (14\% to $21 \%$; Runkle and Heins, 2001). Furthermore, the trial in the United Kingdom showed that the inhibition of stem elongation was adequate to meet the desired height specification as accomplished with the PGR treatments. These results are consistent with McMahon and Kelly (1990), who reported a 48 $\%$ reduction in poinsettia internode length using copper sulphate liquid filters that transmitted a narrow band R: FR ( 655 to $660 \mathrm{~nm}: 725$ to 730 $\mathrm{nm}$ ) of 2.94. However, Mortensen and Strømme (1987) did not observe any height reduction in poinsettia using a copper sulphate FR filter that transmitted a R:FR of 4.10 .

Previous studies have shown that poinsettia extension growth is reduced when the temperature is lowered early in the morning for several hours (DROP; Cockshull et al, 1994; Myster and Moe, 1995). In the United Kingdom trial, the magnitude of the DROP treatment was small due to high ambient temperatures in July and August. Thus, the DROP treatment in this study provided no significant height control compared with plants produced under the control temperature regimen. Although DROP can be applied effectively toward the end of the season, it is generally avoided by commercial growers in the United Kingdom at that point in the season to avoid detrimental effects on bract expansion.

The FR filters in the United Kingdom trial significantly delayed the time to $50 \%$ bract color and to the $50 \%$ visible cyathia stage. However, the FR filter did not affect time to market stage (all but one bract fully colored). The delay in flowering (time to reach $50 \%$ visible cyathia) of plants grown under the FR filter was first observed 21 Oct., but this delay did not increase with time. Thus, the delay could be attributed to a delay in flower induction, rather than development. To our knowledge, the effects of an increased R: FR on flowering of poinsettia have not been previously published. In the short-day plant chrysanthemum (Dendranthema $\times$ grandiflora Kitam.), a high $\mathrm{R}$ : FR delayed flowering in 'Bright Golden Anne' but not in 'Spears' (McMahon, 1999; Rajapakse and Kelly, 1995).

Reducing transmitted R light, which created a very low $R$ : FR, increased internode extension and decreased axillary branching. Combined with plant responses under the FR filter, poinsettia is clearly sensitive to the $R$ : FR and thus can be labelled a shade-avoiding plant. It appears that B light does not play a significant role in mediating stem extension in poinsettia. The relatively small promotion of stem extension under the B-deficient environment may be at least partially attributed to a small increase in the R:FR (Table 1).

In the United Kingdom trial, the problem of declining irradiance toward the end of production was exacerbated by the additional reduction in light intensity due to the continuous use of the spectral filter. As a result, the subjective quality of plants at marketing was lower than that of plants grown without any shading from the filters. To optimize light intensity while reducing FR, spectral filters could be dynamically managed using automatic glasshouse screening mechanisms. For example, FR filters could be deployed only during the first half to two-thirds of the poinsettia production schedule, or filters could be used only during the morning and evening to reduce the natural ambient rise in the $\mathrm{R}: \mathrm{FR}$. Lighting studies with tomato and chrysanthemum(Decoteau and Friend, 1991; Rajapaske et al., 1993) support this approach, but additional studies with poinsettia are warranted before such strategies should be promoted.

Table 2. Effect of temperature and filter treatments in the United Kingdom trial on time to $50 \%$ bract color, $50 \%$ cyathia visible, marketing, and plant height of poinsettia. Filters were installed and the DROP treatment began on 26 and 27 Aug., respectively. The DROP treatment terminated 21 Oct., and plants reached market stage on 18 Nov.

\begin{tabular}{|c|c|c|c|c|c|c|c|}
\hline \multicolumn{3}{|c|}{ Treatment } & \multicolumn{2}{|c|}{ Time to $50 \%$} & \multirow{3}{*}{$\begin{array}{l}\text { Time to } \\
\text { marketing } \\
\text { (days) }\end{array}$} & \multirow{2}{*}{\multicolumn{2}{|c|}{$\begin{array}{l}\text { Plant height } \\
(\mathrm{cm})\end{array}$}} \\
\hline \multirow[b]{2}{*}{ Temperature $^{\mathrm{z}}$} & \multirow[b]{2}{*}{ Filter $^{y}$} & \multirow{2}{*}{$\begin{array}{l}\text { Chlormequat chloride } \\
\text { applications }^{\mathrm{x}}\end{array}$} & \multirow{2}{*}{$\begin{array}{l}\text { Plants showing } \\
\text { bract color (days) }\end{array}$} & \multirow{2}{*}{$\begin{array}{l}\text { Plants with visible } \\
\text { cyathia (days) }\end{array}$} & & & \\
\hline & & & & & & 21 Oct. & 18 Nov. \\
\hline Standard & None & None & $81 \mathrm{a}^{\mathrm{w}}$ & $101 \mathrm{a}$ & $128 \mathrm{a}$ & $28.0 \mathrm{a}$ & $41.8 \mathrm{a}$ \\
\hline Standard & FR & None & $87 \mathrm{~b}$ & $104 \mathrm{~b}$ & $132 \mathrm{a}$ & $21.2 \mathrm{~b}$ & $33.2 \mathrm{a}$ \\
\hline Standard & None & Yes & $78 \mathrm{a}$ & $100 \mathrm{a}$ & $125 \mathrm{a}$ & $20.3 \mathrm{~b}$ & $29.8 \mathrm{~b}$ \\
\hline DROP & None & None & $80 \mathrm{a}$ & $101 \mathrm{a}$ & $117 \mathrm{~b}$ & $26.8 \mathrm{a}$ & $39.4 \mathrm{a}$ \\
\hline $5 \%$ LSD (14 df & & & 2.6 & 1.9 & 4.6 & 3.7 & 4.1 \\
\hline
\end{tabular}

${ }^{2}$ Standard day/night temperature setpoints were $19 / 20^{\circ} \mathrm{C}$ from 2 Aug. to 27 Sept., $16 / 18{ }^{\circ} \mathrm{C}$ from 27 Sept. to 25 Oct., and $16 / 16^{\circ} \mathrm{C}$ from 25 Oct. to final harvest; DROP was similar but with an $8{ }^{\circ} \mathrm{C}$ setpoint decrease for $3 \mathrm{~h}$ beginning at dawn from 27 Aug. to 22 Oct.

${ }^{\mathrm{y}} \mathrm{FR}=$ Filter that reduced transmission of far-red $(700$ to $800 \mathrm{~nm})$ light.

xPlants received 19 applications of chlormequat chloride at $1.5 \mathrm{~mL} \cdot \mathrm{L}^{-1}$ (46\% a.i.).

"Values within columns with the same letter are not statistically different at $P=0.05$. 


\section{Literature Cited}

Aphalo, P.J., C.L. Ballaré, and A.L. Scopel. 1999. Plant-plant signalling, the shade-avoidance response and competition. J. Expt. Bot. 50:1629-1634.

Cockshull, K.E., F.A. Langton, and C.R.J. Cave. 1994. Differential effects of different DIF treatments on chrysanthemum and poinsettia. Acta Hort. 378:15-25.

Decoteau, D.R. and H.H. Friend. 1991. Growth and subsequent yield of tomatoes following end-ofday light treatment of transplants. HortScience 26(12):1528-1530.

Erwin, J.E. and R.D. Heins. 1995. Thermomorphogenic response in stem and leaf development. HortScience 30:940-949.

Fisher, P.R. and D.C. Mackensen. 1997. UNH FloraTrack for Poinsettia. Version 1.0. Univ. of New Hampshire. 5 June 2003. <http://www.ecke. $\mathrm{com} / \mathrm{html} / \mathrm{h} \_$points/points_graphical.html $>$.

Garner, L., F.A. Langton, and T. Björkman. 1997. Commercial adaptations of mechanical stimulation for the control of transplant growth. Acta Hort. 435:219-230.

Heins, R. and J. Erwin. 1990. Understanding and applying DIF. Greenhouse Grower 8(2):73-78

Holmes, M.G. and H. Smith. 1977a. The function of phytochrome in the natural environment II. The influence of vegetation canopies on the spectral energy distribution of natural daylight. Photochem. Photobiol. 25:539-545.

Holmes, M.G. and H. Smith. 1977b. The function of phytochrome in the natural environment IV. Light quality and plant development. Photochem. Photobiol. 25:551-557.

Johjima, T., J.G. Latimer, and H. Wakita. 1992. Brushing influences transplant growth and subsequent yield of four cultivars of tomato and their hybrid lines. J. Amer. Soc. Hort. Sci. 117:384-388.

Jordan, E.T., P.M. Hatfield, D. Hondred, M. Talon,
J.A.D. Zeevaart, and R.D. Vierstra. 1995. Phytochrome Aoverexpression in transgenic tobacco. Plant Physiol. 107:797-805.

Langton, F.A. 1998. Regulation of stem extension by temperature. p. 191-203. In: K.E. Cockshull, D. Gray, G.B. Seymore and B. Thomas (eds.). Genetic and environmental manipulation of horticultural crops. CABI, Wallingford, U.K.

Langton, F.A. and K.E. Cockshull. 1997. Is stem extension determined by DIF or by absolute day and night temperature? Scientia Hort. 69:229-237.

Liptay, A., P. Sikkema, and W. Fonteno. 1997. Transplant production and performance: Transplant growth control through water stress, p. 51-53. In: C. Vavrina (ed.). Transplant Proc., Ohio State Univ., Columbus.

McMahon, M.J. 1999. Development of chrysanthemum meristems grown under far-red absorbing filters and long or short photoperiods. J. Amer. Soc. Hort. Sci. 124(5):483-487.

McMahon, M.J. and J.W. Kelly. 1990. Control of poinsettia growth and pigmentation by manipulating light quality. HortScience 25:1068 (Abstr.).

McMahon, M.J.,J.W.Kelly, and D.R. Decoteau. 1990. Spectral transmission of selected greenhouse construction and nursery shading material. $\mathrm{J}$. Env. Hort. 8:118-121.

Melton, R.R. and R.J. Dufault. 1991. Nitrogen, phosphorus, and potassium fertility regimes affect tomato transplant growth. HortScience 26:141-142.

Mortensen, L.M. and E. Strømme. 1987. Effects of light quality on some greenhouse crops. Scientia Hort. 33:27-36.

Myster, J. and R. Moe. 1995. Effect of diurnal temperature alterations on plant morphology in some greenhouse crops - Amini review. Scientia Hort. 62:205-215.

Oyaert, E., E. Volkaert, and P.C. Debergh. 1999. Growth of chrysanthemum under colored plastic films with different light qualities and quantities.
Scientia Hort. 79:195-205.

Payne, R.W. 2000. Design and analysis of experiments, p. 235-412. In: R.W. Payne (ed.). The guide to Genstat-Part 2: Statistics. VSN Intl., Oxford, U.K.

Rajapakse, N.C., M.J. McMahon, and J.W. Kelly. 1993. End of day far-red light reverses height reduction of chrysanthemum induced by $\mathrm{CuSO}_{4}$ spectral filters. Scientia Hort. 53:249259.

Rajapakse, N.C. and J.W. Kelly. 1995. Spectral filters and growing season influence growth and carbohydrate status of chrysanthemum. J.Amer. Soc. Hort. Sci. 120:78-83.

Rajapakse, N.C., R.E. Young, M.J.McMahon, and R. Oi. 1999. Plant height control by photoselective filters: Current status and future prospects. HortTechnology 9:618-624.

Runkle, E.S. and R.D. Heins. 2001. Specific functions of red, far red, and blue light in flowering and stem extension of long-day plants. J. Amer. Soc. Hort. Sci. 126:275-282.

Sager J.C., W.O Smith, J.L. Edwards, and K.L. Cyr. 1988. Photosynthetic efficiency and phytochrome photoequilibria determination using spectral data. Trans. ASAE 31:1882-1889.

Smith, H. 1982. Light quality, photoperception and plant strategy. Annu. Rev. Plant Physiol. 33:481-518.

Ueber, E. and L. Hendriks. 1992. Effects of intensity, duration and timing of a temperature drop on the growth and flowering of Euphorbia pulcherrima Willd. Ex Klotsch. Acta Hort. 327:33-40.

United States Dept. of Agriculture (USDA), National Agricultural Statistics Service. 2002. Floriculture crops 2001 Summary. 5 June 2003. $<$ http://usda.mannlib.cornell.edu $>$.

van Haeringen, C.J., J.S. West, A. Gilbert, P. Hadley, S. Pearson, A.E. Wheldon, and R.G.C. Henbest. 1998. The development of solid spectral filters for the regulation of plant growth. Photochem. Photobiol. 67:407-413. 